\title{
THE CAPACITY OF THE SANNA RIVER IN CONDITIONS OF THE RELIABLE FLOW AND THE CONTROL DISCHARGES OF THE WEIR IN ZAKLIKÓW
}

\author{
Bogusław Michalec
}

\begin{abstract}
Summary
The aim of the study was to determine the capacity of a selected section of the Sanna river, designated below the lower site of the weir in Zaklików. The capacity calculations included the conditions of flood water discharge, i.e. the reliable flow and the control flow, determined in accordance with the Regulation of the Minister of the Environment on technical conditions that should be ensured for the hydrotechnical structures and their locations. The paper presents the consequences of changes in the regulations regarding the determination of building type, for which reliable flow and control discharges are determined. These modifications in the regulations have an impact on changes in the determination of the probability value for water discharges related to the analysed weir. The calculation of the capacity of the tested section also took into account its technical condition, specifying the variant of calculations for the lack of maintenance works, i.e. for the current state and for the state after maintenance works, consisting in mowing vegetation on slopes and shaping the surface of river bottom, removing pits and shallows. The results of the calculations of capacity of the measured cross-sections showed that the performance of maintenance works will convey the flow of a $Q_{3 \%}$ reliable flow in the Sanna river, while the $Q_{1 \%}$ control flow will not fit into the riverbed and will cause inundation of the adjacent areas.
\end{abstract}

\section{Key words}

reliable flow $\bullet$ control flow $\bullet$ capacity $\bullet$ damming $\bullet$ inundation

\section{Introduction}

Maintaining the riverbeds and the accompanying hydrotechnical structures, such as flood embankments, reservoir barriers, weirs, in good technical condition in accordance with the Water Law Act [Art. 188, Journal of Laws 2017, item 1566, as amended - Art. 188, Dz. U. 2017, poz. 1566 z późn. zm.] falls under the competence of the waters owner. Planning the maintenance works for a given watercourse depends, among others, on the location of a section or the level of riverbed development. Properly planned and carried out maintenance of a watercourse bed can significantly reduce flood risk in the adjacent areas. This should be supported by constantly developed and published 
guidelines and studies [Bojarski et al. 2005, Dubel et al. 2018, Prus et al. 2018], as they provide with detailed descriptions of the types and methods of maintenance works, with regard to their overall effects.

The negative effects of floods are to be limited by properly designed dimensions of the discharge devices of water structures, as well as ensuring the appropriate capacity of watercourse beds. For this purpose, it is necessary to set the correct value of the reliable flow rate. In accordance with the Regulation of the Minister of the Environment [Journal of Laws No. 86, 2007 - Dz. U. Nr 86, 2007] on the technical conditions to be met by hydrotechnical structures and their location, the reliable flow is a flow 'on the basis of which hydrotechnical structures are designed'. This flow, as a flow with a certain probability of occurrence (overflowing), is determined on the basis of validity class of a hydrotechnical structure (Table 1).

Table 1. The probability of the reliable flow and the control flow for hydrotechnical structures Annex 4 to the Regulation of the Minister of the Environment [2007]

\begin{tabular}{|c|c|c|c|c|c|c|}
\hline \multirow{2}{*}{ No. } & \multirow{2}{*}{ Type of construction } & \multirow{2}{*}{$\begin{array}{l}\text { Discharge } \\
\text { flows }\end{array}$} & \multicolumn{4}{|c|}{$\begin{array}{l}\text { The probability } \\
\mathrm{p} \text { [\%] for a class }\end{array}$} \\
\hline & & & I & II & III & IV \\
\hline \multirow{2}{*}{1} & \multirow{2}{*}{$\begin{array}{l}\text { Structures founded on a easily washable base, made of } \\
\text { non-rock soils, rock rubble or soft rocks, and all earth } \\
\text { structures, but without flood embankments }\end{array}$} & reliable flow & 0.1 & 0.3 & 0.5 & 1.0 \\
\hline & & control flow & 0.02 & 0.05 & 0.2 & 0.5 \\
\hline \multirow{2}{*}{2} & \multirow{2}{*}{ Other structures, including flood embankments } & reliable flow & 0.5 & 1.0 & 2.0 & 3.0 \\
\hline & & control flow & 0.1 & 0.3 & 0.5 & 1.0 \\
\hline
\end{tabular}

The determined value of the probability of flow for the reliable flow for some hydrotechnical structures, to which the pre-2007 regulations were applied, may turn out to be different in the view of current regulations. In the repealed Regulation of the Minister of the Environment of 1996 [Journal of Laws No. 21, items 110 and 111, 2007 - Dz. U. $\mathrm{Nr} 21$, poz. $110 \mathrm{i} 111,2007]$ on the technical conditions to be met by water management structures and their location is given in Table 5 of this Regulation in the row no. 1 in the following entry 'structures which are damaged by their overflow', and in the row no. 2: 'buildings which are not damaged by their overflow'. The entries in these rows, specifying the type of structure, have been replaced in the current Regulation with those presented in the quoted Annex 4 (Table 1).

This means that in the repealed Regulation of 1996 the hydrotechnical structures were distinguished only by their damage in the case there is an overflow, but the flow rate was not defined for these conditions. On the other hand, in the current regulation, the criterion for the division of hydrotechnical structures is related to the type of soil in the foundation of the structure. Pursuant to the 1996 Regulation, a water damming weir, as a class IV hydrotechnical structure, is 'a structure that is not damaged by its over- 
flow' (row no. 2) requires the determination of the reliable flow $\left(Q_{m}\right)$ as a flow with the probability of $3 \%$. However, in the view of the regulations in force, i.e. according to the Regulation of 2007, the reliable flow for such weir should be determined as a flow with the probability of $1 \%$ (row no. 1 in Table 1 ). The above example shows that when applying for a water permit for damming of a hydrotechnical structure, constructed according to a design from before the Regulation of the Minister of the Environment of 2007, it will be necessary to revise the value of the reliable flow in order to determine its class. It is also important to refer to the historic regulations from 1967, developed by the then Central Office for Water Management. Those provisions, concerning the determination of the reliable flow for a given class of validity of water structures, were in force until 1996. Pursuant to those provisions, the water structures highlighted in row no. 1, as in Table 1 , according to the legislation in force, are defined as: 'earth erratic dams with structures and spillway facilities for damming over $10 \mathrm{~m}$ in lowland areas and over $3 \mathrm{~m}$ in mountainous areas'. It should be added that the probability values adopted in accordance with the provisions of the Central Office for Water Management of 1996 have not changed in the regulations of 1996 and 2007. Only the description of the structure's division has changed. According to this division, if a weir's damming height does not exceed $5 \mathrm{~m}$, it is classified as a different structure than that mentioned in row no. 1, and the reliable flow was defined as a flow with a probability of occurrence of $3 \%$. This means that also in the case of hydrotechnical structures for which calculation flows have been estimated, i.e. reliable flow $\left(Q_{m}\right)$ and control $\left(Q_{k}\right)$ flow, it will be necessary to adjust the probability values, calculated as to the 1967 provisions, in accordance with the provisions in force, when applying for a permit for damming. Consequently, for the case in question, it may appear that the reliable flow as a flow with a probability of $1 \%$ according to the provisions of the 2007 Regulation cannot be safely conveyed in the weir's light, since it was designed before 2007 for a reliable flow with a probability of 3\%. Furthermore, under the current law, it may turn out that the examined hydrotechnical structure has been designed for much smaller flow than required.

The 2007 Regulation does not define the conditions for water flow below the hydrotechnical structure, but the watercourse bed below the structure, especially in urban areas, should also have a capacity to sustain the discharge water flow. For embanked watercourses the reliable flow is determined in accordance with the 2007 Regulation as a flow with a probability between $3 \%$ for the class IV embankment and $0.5 \%$ for class I (Table 1).

River regulation projects have adopted reliable flow as a flow with a probability of occurrence of $50 \%$. Considering the protection of a valley used for agriculture against high waters, a reliable flow for a riverbed is adopted with the probability between $10-50 \%$. However, the formation of the valley and its degree of development should be considered while assessing the probability value. According to Bojarski et al. [2005], reliable flow in the calculation of the watercourse capacity forms the basis for a design of the control cross-sections and is intended to fill in the entirety of the proposed control cross-section of the bed. The watercourse cross-section on the crown of a riffle was selected for the calculation. 'Good-Practice Manual of Sustainable Maintenance of 
Mountain Streams and Rivers in Southern Poland' [Bojarski et al. 2005] indicates the adoption of a reliable flow for gravel-bottomed watercourses. From the given criteria it follows that the reliable flow for watercourses in areas of intensive development is determined as a flow with a probability of an overflow below $50 \%$ in a single year and, in the case of bipartite beds, a flow with a probability of $\mathrm{p}=67 \%$ is assumed for its lower part. Whereas, for beds in areas covered by grassland, forests and wasteland - flow with a probability of $\mathrm{p}=100 \%$ is adopted. Bojarski et al. [2005] report that an analysis of vertically stable natural rivers showed that in the vast majority of cases the probability of a full-bed flow was less than $50 \%$.

The synthetic analysis of the amendments to the provisions on the determination of calculation flows for hydrotechnical structures, in connection with the determination of the proposed capacity of the watercourses, in respect with the elimination or reduction of the flood risk, provided the basis for an analysis of the conditions for discharge of high waters from a small reservoir. The aim of the work was to determine the capacity of the selected section of the river, designated below the lower site of the weir. The capacity was determined under the conditions of discharge of high waters, taking the calculation flows as reliable flow and control flow, determined in accordance with the Regulation of the Minister of the Environment [Dz. U. Nr 86, 2007] on the technical conditions to be met by hydrotechnical structures and their location.

\section{Research site}

A $216 \mathrm{~m}$ long section of the Sanna river was selected for the study, ranging below the ends of protections of the lower surface overflow sites of the weir in Zaklików (Fig. 1 ), which in result of damming created a so-called backwater reservoir (reference 3 in Figure 1).

The area of this reservoir is about 2.10 ha. and it is bordered to the west by a frontal levee with a built-in weir and lateral levees that turn into the backwater embankment of the Sanna river [Projekt budowlany 2003]. This weir is located in the Zaklików municipality, in the Stalowa Wola poviat in the Podkarpackie Voivodeship. It is designed for water supply to power plants and water reservoirs, and, according to the 'Construction Project' [Projekt budowlany 2003], apart from damming up water, its task is also to safely discharge high waters. A weir (no. 1 in Fig. 1) damming the water to the ordinate $177.70 \mathrm{~m}$ a.s.l. functions as a spillway of a small water reservoir in Zaklików. Due to the damming height of $2.2 \mathrm{~m}$, the weir has been classified in the IV validity class of hydrotechnical structures. The weir cross-section closes the Sanna catchment area with an area of $226.5 \mathrm{~km}^{2}$.

The weir, as a reinforced concrete structure in the body of an earth dam, has a spillway with three spans, where the two extreme spans are closed with movable closures, and the central span has a water damming diaphragm to maintain the normal damming level. In order to guarantee fish a suitable migration route, the weir was equipped with a fish ladder. The facility is also equipped with a small hydroelectric power plant [Ogólna ocena stanu technicznego... 2015]. On the right bank, approx. $40 \mathrm{~m}$ from the 
weir in the frontal levee, there is a concrete structure, which dams water on a recreation and breeding reservoir (no. 4 in Fig. 1) called Zalew in Zaklików. Under normal use conditions, the river below the weir is fed by the above-mentioned water devices. Moreover, these devices, together with fish ponds of an area of 3.37 ha in the vicinity of the weir, are part of the water unit in the town of Zaklików [Ogólna ocena stanu technicznego... 2015].

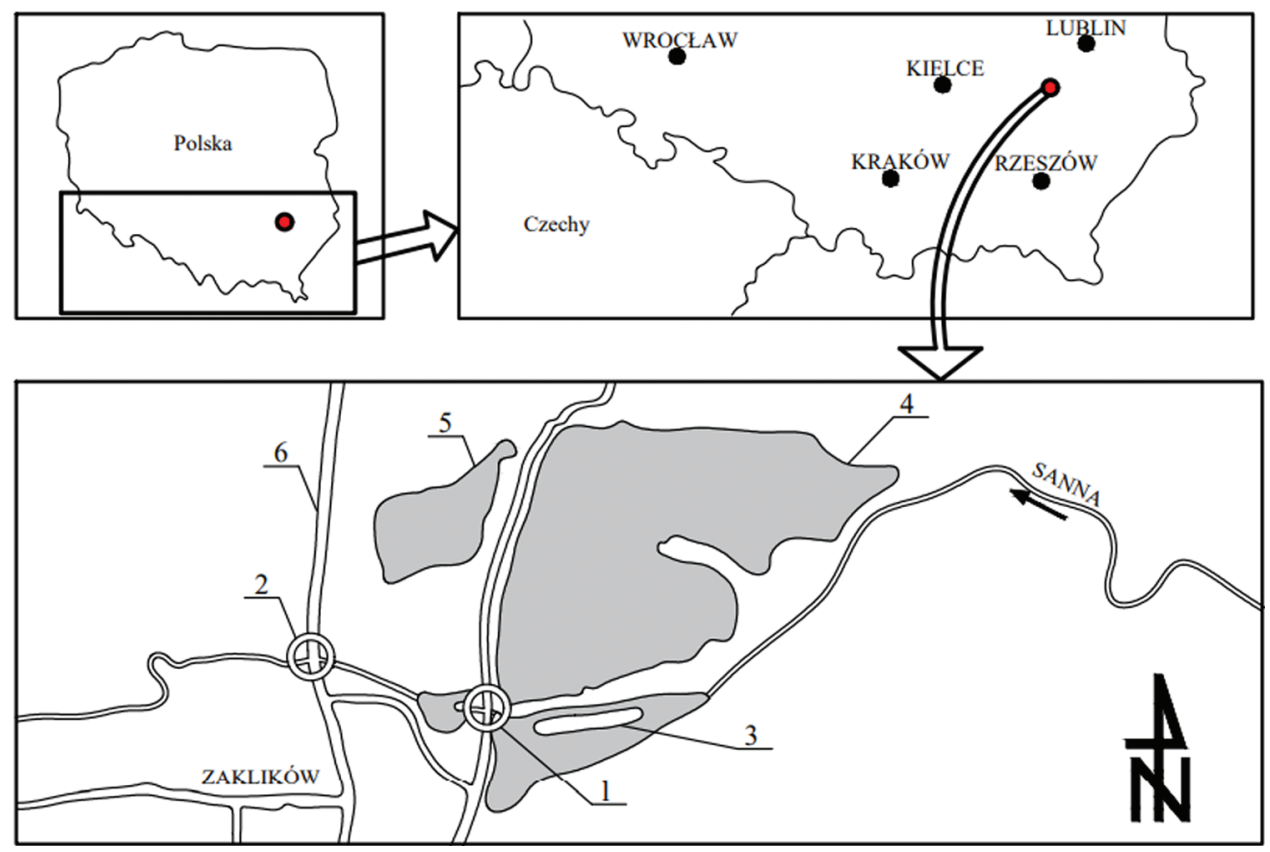

Source: Author's own study

Fig. 1. Location of the weir (1) in Zaklików; 2 - bridge, 3 - backwater reservoir, 4 - water reservoir in Zaklików, 5 - pond, 6 - voivodeship road No. 855

The calculation flows for the weir spillway, which is a hydrotechnical structure of the IV validity class, were determined in accordance with the then binding Regulation of the Minister of the Environment of 1996 [Dz. U. Nr 21, poz. 110 i 111, 2007]. According to the 'Construction design' [Projekt budowlany 2003], a 3\% probability was adopted for the reliable flow and for the control flow - 1\%. These flows according to the 'Construction design' are respectively - the reliable flow $Q_{m}=Q_{3 \%}=40.81 \mathrm{~m}^{3} \cdot \mathrm{s}^{-1}$, and the control flow $Q_{k}=Q_{1 \%}=58.38 \mathrm{~m}^{3} \cdot \mathrm{s}^{-1}$. However, in the 'Water management manual' [Instrukcja gospodarowania wodą 2015], the reliable flow $Q_{m}=Q_{3 \%}=45.82 \mathrm{~m}^{3} \cdot \mathrm{s}^{-1}$, and the control flow $Q_{k}=Q_{1 \%}=58.23 \mathrm{~m}^{3} \cdot \mathrm{s}^{-1}$. The discrepancies between data included in the 'Construction Project' and the 'Water management manual' also apply to other types of flows, including flows with a determinate probability (Table 2). According to the 'Construction design', the 
weir was located at $\mathrm{km} 29+540$ of the Sanna river, while according to the 'Water management manual', it is located at $\mathrm{km} 31+489$ of the Sanna river.

Table 2. Flow rate $\mathrm{Q}\left[\mathrm{m}^{3} \cdot \mathrm{s}^{-1}\right]$ according to 'Construction design' [2003] and to 'Water management manual' [2015]

\begin{tabular}{|c|c|c|}
\hline \multirow{2}{*}{$\begin{array}{c}\text { Probability } \\
\mathrm{p}[\%]\end{array}$} & $\begin{array}{c}|c| \\
\text { 'Plow rate } \mathrm{Q}\left[\mathrm{m}^{3} \cdot \mathrm{s}^{-1}\right] \text { according to } \\
\text { 'Construction design' [2003] }\end{array}$ & $\begin{array}{c}\text { 'Instrukcja gospodarowania wodą [2015] } \\
\text { 'Water management manual' [2015] }\end{array}$ \\
\hline 1 & 58.38 & 58.23 \\
\hline 3 & 40.81 & 45.82 \\
\hline 5 & 32.09 & 40.41 \\
\hline 10 & 24.40 & 32.49 \\
\hline 20 & 15.16 & 24.46 \\
\hline 50 & 5.02 & 4.32 \\
\hline
\end{tabular}

The studied section of the Sanna river below the lower weir of the Zaklików reservoir runs through built-up areas. Along the left bank of the river there is an asphalt road and adjoining buildings. The areas along the right bank are covered with vegetation, next to a plot with a sports stadium [Hołody 2020]. The studied section of the watercourse is crossed by a road bridge which is part of the Stalowa Wola-Olbięcin voivodeship road no. 855, which is classified as ' $G$ ' road. The reinforced concrete bridge was built in 2014 [Hołody 2020]. The abutments of this bridge on the side of upper water were located at kilometre $31+437$ of the Sanna, consistent with the kilometre of the river adopted according to the 'Water management manual'.

\section{Research methodology}

Field studies of the selected section of the Sanna riverbed were carried out on $20^{\text {th }}$ November 2019 and 27 $7^{\text {th }}$ May 2020. During the research, an inventory of the Sanna riverbed was taken in order to determine the roughness coefficients. Eight crosssections were determined (Fig. 2) and geodetic measurements of the riverbed were performed in these cross-sections, as well as measurements of the longitudinal gradient of the bottom. Geodetic measurements were made with the TOPCON AT-G7N leveller. Inventory geodetic measurements of bridge structures were also carried out in order to determine their dimensions, as well as the skewness of their longitudinal axis of the roadway in relation to the riverbed axis. Locations of the so-called bridge cross-sections, used to calculate the capacity of bridges, were adopted in accordance with the Regulation of the Minister of Transport and Maritime Economy on technical conditions to be met by road engineering structures and their location [Dz. U. 2000]. 


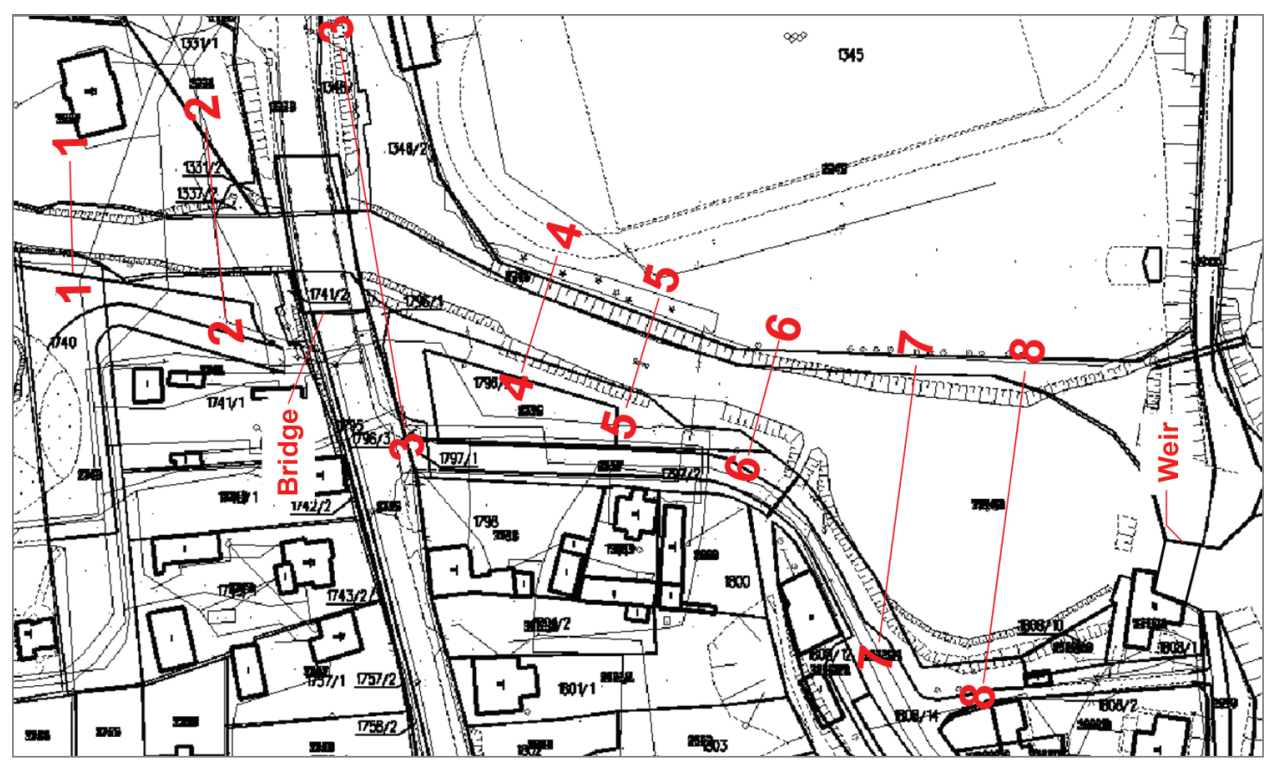

Source: Author's own study

Fig. 2. Location of measurement cross-sections of the studied section of the Sanna River

The calculation of the capacity of each cross-section was performed in two hydraulic variants, i.e.: for the current state - with high vegetation in the riverbed and on the slopes, which were the measurement conditions; and for the state after maintenance works - in the absence of high vegetation that could potentially disturb the flood waters flow. The calculations included the variability of the riverbed construction, separately determining the values of roughness parameters for the bottom, which is dominated by sandy material with reed vegetation, and for slopes that were intensively covered with tall grass at the time of research. The value of the roughness coefficient $n$ according to Manning was taken from the VenTe Chow tables [Książyński et al. 2000] on the basis of the riverbed inventory. The adopted values of the roughness coefficient for individual cross-sections are presented in Table 3 [Hołody 2020]. The mean water flow rate for the maximum filling in the riverbed was calculated by the Chezy formula, and then for the determined cross-sectional area with this filling, the water flow rate was calculated as the so-called bank waters. This flow, designating the maximum cross-section capacity, was compared with the discharge flows from the weir, assuming flows with a certain probability included in the 'Water management manual'. According to the 'Water Management manual', proper operation of the weir in Zaklików should ensure a safe passage of these flows through its spillway to the lower site.

On the basis of the Regulation of the Minister of Transport and Maritime Economy of $30^{\text {th }}$ May 2000 on the technical conditions to be met by road engineering structures and their location [Journal of Laws 2000, No. 63, item 735, as amended - Dz. U. 2000 
$\mathrm{Nr}$ 63, poz. $735 \mathrm{z}$ późn. zm.], calculations were made for basewater damming height $(\Delta Z)$ in front of the bridge located along the road no. 855. Calculations of the damming height of water in the bridges' light in accordance with this regulation are also presented in the work of Mikołajczyk et al. [2019].

Table 3. The value of the roughness coefficients $n$ in measurement cross-sections for the established calculation conditions [Hołody 2020]

\begin{tabular}{|c|c|c|c|c|}
\hline \multirow{2}{*}{ Cross-section No } & \multicolumn{3}{|c|}{ Roughness coefficient $n\left[\mathrm{~m}^{-1 / 3} \cdot \mathrm{s}\right]$ acc. to VenTe Chow } \\
\cline { 2 - 4 } & \multicolumn{2}{|c|}{ Current status } & \multicolumn{2}{|c|}{ After maintenance } \\
\cline { 2 - 4 } & bottom & river bank & bottom & river bank \\
\hline $1(\mathrm{~km} \mathrm{31+221)}$ & 0.040 & 0.035 & 0.030 \\
\hline $2(\mathrm{~km} \mathrm{31+246)}$ & 0.040 & 0.035 & 0.030 \\
\hline $3(\mathrm{~km} \mathrm{31+281)}$ & 0.035 & 0.030 & 0.0275 \\
\hline $4(\mathrm{~km} 31+325)$ & 0.050 & 0.035 & 0.030 \\
\hline $5(\mathrm{~km} \mathrm{31+349)}$ & 0.050 & 0.035 & 0.030 \\
\hline $6(\mathrm{~km} \mathrm{31+384)}$ & 0.050 & 0.035 & 0.030 \\
\hline $7(\mathrm{~km} \mathrm{31+410)}$ & 0.045 & 0.035 & 0.030 \\
\hline $8(\mathrm{~km} \mathrm{31+437)}$ & 0.045 & 0.035 & 0.030 \\
\hline
\end{tabular}

\section{Results}

Developing the cross-sections allowed to calculate their area for the maximum filling, corresponding to the bank waters in each of the two adopted calculation variants. The calculations of capacity in the first stage were made without taking into account the influence of the bridge along the voivodeship road no. 855, and the results of these calculations are presented in Table 4. The hydraulic calculations adopted the measurement of mean gradient of the river bottom $-2.9 \%$. The mean gradient of the water table on the studied river section, calculated on the basis of geodetic measurements, is $2.0 \%$.

The next stage involved calculating the flood waters flow damming in the bridge's light along the voivodeship road no. 855. On the basis of geodetic measurements, it was found that the span of the bridge, calculated between the abutments, is $25 \mathrm{~m}$, while its width is $14 \mathrm{~m}$. The bridge capacity calculations were made for the maximum reliable flow $Q_{m}=Q_{3 \%}$, control flow $Q_{k}=Q_{1 \%}$ and a flow with a probability of $0.5 \%$. The flow $Q_{0.5 \%}$ was determined as extrapolated from the regression curve developed for the data in Table 2, i.e. for the probability $(\mathrm{p})$ and the corresponding flow rate $(Q)$ given in the 'Water Management Manual' [2015]. From the developed regression curve (Fig. 3) in the form of $Q=-13.22 \ln (p)+60.554$, for which the correlation coefficient $R$ was 0.987 , the calculated flow rate with a probability of $0.5 \%$ is $69.72 \mathrm{~m}^{3} \cdot \mathrm{s}^{-1}$. 
Table 4. Results of the calculation of the capacity of the selected cross-sections of the studied section of the Sanna

\begin{tabular}{|c|c|c|c|c|}
\hline \multirow{2}{*}{ Cross-section No } & \multicolumn{2}{|c|}{$\begin{array}{c}\text { Maximum flow (riverbank flow) } \\
\mathbf{Q}_{\max }\left[\mathrm{m}^{3} \cdot \mathrm{s}^{-1}\right]\end{array}$} & $\begin{array}{c}\text { Cross-section area } \\
\mathbf{A}\left[\mathrm{m}^{2}\right]\end{array}$ & $\begin{array}{c}\text { Filling in the riverbed } \\
{[\mathrm{m}]}\end{array}$ \\
\cline { 2 - 3 } & Current & After maintenance & 17.53 & 2.37 \\
\hline 1 & 30.58 & 37.79 & 26.83 & 1.99 \\
\hline 2 & 45.94 & 58.23 & 92.56 & 4.03 \\
\hline 3 & 229.07 & 338.27 & 25.03 & 2.26 \\
\hline 4 & 38.11 & 54.31 & 25.10 & 2.31 \\
\hline 5 & 37.03 & 50.83 & 21.27 & 2.01 \\
\hline 6 & 28.54 & 42.42 & 95.81 & 2.22 \\
\hline 7 & 161.46 & 204.90 & 116.92 & 2.69 \\
\hline 8 & 218.19 & 297.54 & & \\
\hline
\end{tabular}

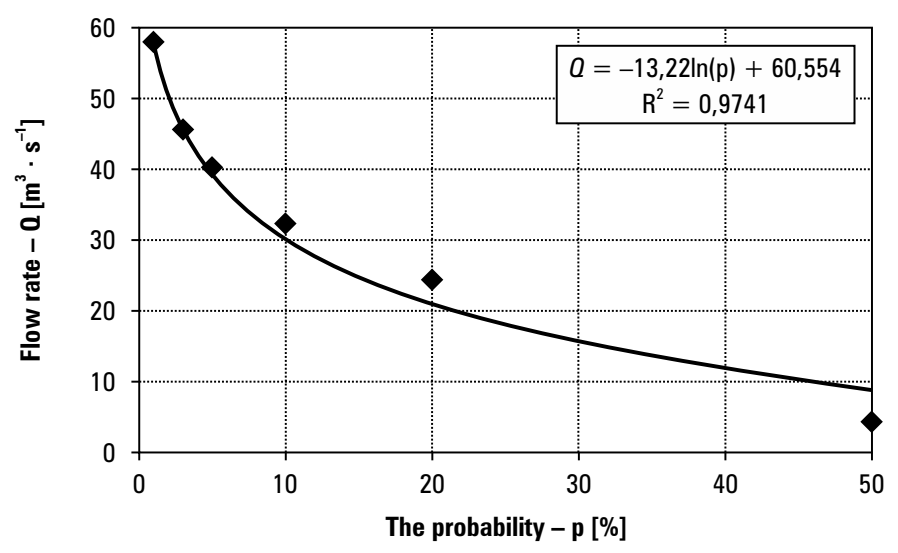

Fig. 3. Probability curve developed for data in Table 2 - flow rate acc. to 'Water management manual' [2015]

The calculated contraction factor $M$ for each of the flows, i.e. $Q_{3 \%}, Q_{1 \%}, Q_{0.5 \%}$ is 1 , hence the loss coefficient depending on the degree of narrowing of the watercourse between the abutments and their shape $\left(K_{0}\right)$ is zero, also each of the corrections, i.e. $\Delta K_{\rho} \Delta K_{e}$ and $\Delta K_{\varphi}$ are zero. Thus, the loss coefficient $(K)$ being the sum of these four components is zero, and the first component of the sum is zero. The total damming of the analysed flows, both in the current state and after maintenance, is zero. This means that the bridge of the voivodeship road no. 855 has no impact on the damming of the analysed flows. 
The calculated capacity in the selected sections leads to a conclusion that in the current state, i.e. without maintenance procedures, in sections $1,4,5$ and 6 , the measurable flow $Q_{m}=Q_{3 \%}=45.82 \mathrm{~m}^{3} \cdot \mathrm{s}^{-1}$ given in the 'Water management manual' [2015]. On the other hand, the maintenance procedures will help the water flow $Q_{m}$ only in cross-section 4 and 5. Maintenance procedures will not ensure the capacity of sections 1, 4, 5 and 6, corresponding to the control flow $Q_{k}=Q_{1 \%}$ amounting to $58.23 \mathrm{~m}^{3} \cdot \mathrm{s}^{-1}$. Also, a flow with a probability of $0.5 \%$ due to the lower capacity of sections $1,2,4,5$ and 6 will result in flooding of the adjacent areas.

\section{Summary and conclusions}

The determined capacity of the studied short section of the Sanna river below the lower weir site in Zaklików turned out to be smaller than the flood waters flows, i.e. the reliable flow $\left(Q_{3 \%}\right)$ and the control flow $\left(Q_{1 \%}\right)$. These flows, i.e. the reliable flow, used for measuring the weir, and the control flow, used for testing the safety of the weir in extraordinary load conditions, in accordance with paragraph 65 (1) of the 2007 Regulation, should be conveyed safely by the discharge devices of a hydrotechnical structure into the riverbed or channel below the facilities. This is ensured by a section of the Sanna about 60 meters long from the ends of the protections of the weir's lower site. In this section, two cross-sections were determined, no. 7 and 8 , the capacity of which, regardless of the maintenance status of the riverbed, was several times greater than the flows assumed in the calculations. While, in the segment from cross-section 6 to cross-section 4 , located in front of the bridge, the length of which is about 70 meters, the capacity of the Sanna in current state, i.e. without maintenance procedures, causes the reliable flow to overflow the riverbed. Excessive vegetation reduces the capacity of riverbeds, which is confirmed by the works of Wu and He [2009], Wolski et al. [2018], Fernandes et al. [2018]. Carrying out maintenance works, consisting in mowing high vegetation, will enable the Sanna bed to tolerate the reliable flow. While the control flow, when exceeding the riverbed, will flood the adjacent areas. The bridge along the voivodeship road no. 855 does not have any adverse effects on the flow conditions of the reliable flow and the control flow. The calculated height of damming these flows in this bridge's light is zero, regardless of the maintenance status of the Sanna riverbed. In this analysis, the reliable flow and control flows for the weir in Zaklików were determined as flows with a probability of 3 and $1 \%$, respectively. According to the regulations in force, the reliable flow and control flows should be determined as having the probability of 1 and $0.5 \%$ (Table 1 ). This means that the cross-sections of the tested section should accommodate calculation flows with a higher flow rate. These flows, amounting to respectively: $Q_{1 \%}=58.23 \mathrm{~m}^{3} \cdot \mathrm{s}^{-1}$ and $Q_{0.5 \%}=69.72 \mathrm{~m}^{3} \cdot \mathrm{s}^{-1}$, exceeding the cross-sections 1, 2, 4, 5 and 6, even after maintenance works in the Sanna riverbed, will flood the adjacent areas. The presented analysis of the Sanna riverbed capacity below the Zaklików weir indicates a potential risk of flooding the areas in the vicinity of the river. As a result of intense rainfall, these areas were flooded in May 2019 [Hołody 2020]. Such a situation should not have happened, because as part of the implementa- 
tion of the weir, funding was obtained from EU funds for the 2004-2006 period, as a project in two categories - safety and environmental protection, which should be met by this facility.

The guidelines provided in the 'Good-Practice Manual of Sustainable Maintenance of Mountain Streams and Rivers in Southern Poland' (Zasady dobrej praktyki w utrzymaniu rzek i potoków górskich) [Bojarski et al. 2005] for determining the flow rate for riverbeds in order to maintain and restore the conditions for flood water retention in floodplains of Carpathian rivers and streams do not have practical application in case of the studied section of the Sanna. Bojarski et al. [2005] claim that for areas with an intensive development, especially of urban type, a flow with a lower probability than $50 \%$ and, however, as high as possible should be assumed. The reliable flow for the bed assumed should be 'sufficient to accommodate flood waters that cannot be otherwise drained or retained'. Specified for the Sanna river in 'Water management manual' [2015] flow with a $50 \%$ probability, amounting to $4.32 \mathrm{~m}^{3} \cdot \mathrm{s}^{-1}$, cannot be considered reliable enough for its riverbed, as it does not secure the flow of flood waters. Under the conditions of water discharge from hydrotechnical structures, the assessment of the riverbed capacity should not take into account flows with a probability of $50 \%$, despite the fact that, according to Strużyński [2006], in unregulated rivers $Q_{50 \%}$ is usually a bank flow and does not cause flood damage.

According to Prus et al. [2018], analyses of flood hazard and risk maps were performed for larger rivers based on hydraulic modelling, and their results are available on the KZGW Hydroportal. For the Sanna, in the studied section, as well as for the entire catchment area above the Zalikowo weir, flood hazard and flood risk analyses have not yet been carried out. The obtained results may be helpful in the development of such analyses, as well as in design and planning works.

\section{References}

Bojarski A., Jeleński J., Jelonek M., Litewka T., Wyżga B., Zalewski J. 2005. Zasady dobrej praktyki w utrzymaniu rzek i potoków górskich. Ministerstwo Środowiska, Departament Zasobów Wodnych, Warszawa, 141.

Dubel A., Grygoruk M., Pawlaczyk P., Prus P., Wybraniec K. 2018. Katalog dobrych praktyk w zakresie robót hydrotechnicznych i prac utrzymaniowych wraz z ustaleniem zasad ich wdrażania. MGGP, Kraków, 152.

Fernandes J.N., Leal J.B., Cardoso A.H. 2018. Influence of floodplain and riparian vegetation in the conveyance and structure of turbulent flow in compound channels. E3S Web of Conferences, 40/06035, 1-8.

Instrukcja gospodarowania wodą - piętrzenie wód na istniejącym jazie, rzeka Sanna, w km 31+489. 2015. Conseko-Safage SA, Kraków.

Książyński K., Jeż P., Gręplowska Z. 2000. Tablice do obliczeń hydraulicznych. Wyd. PK, Kraków.

Mikołajczyk B., Michalec B., Strutyński M. 2019. Preliminary assessment of the impact of Wrocławski bridge in Gliwice on flood flow in Kłodnica river. Geomatics, Landmanagement and Landscape, 4, 231-241. 
Pietraszewski D., Marszał L., Zięba G., Przybylski M., Zieliński P. 2008. Ichtiofauna systemu rzeki Sanny. Rocz. Nauk. PZW, 21, 129-146.

Projekt budowlany. Budowa jazu na rzece Sanna w miejscowości Zaklików, woj. podkarpackie. Część opisowa. Biuro Studiów i Projektów Gospodarki Wodnej Rolnictwa w Warszawie, 2003.

Prus P., Popek Z., Pawlaczyk P. 2018. Dobre praktyki utrzymania rzek. WWF, Polska.

Rozporządzenie Ministra Środowiska z dnia 20 kwietnia 2007 r. w sprawie warunków technicznych, jakim powinny odpowiadać budowle hydrotechniczne i ich usytuowanie. Dz. U. 2007, Nr 86, poz. 579.

Rozporządzenie Ministra Transportu i Gospodarki Morskiej z dnia 30 maja 2000 r. w sprawie warunków technicznych, jakim powinny odpowiadać drogowe obiekty inżynierskie i ich usytuowanie. Dz. U. $2000 \mathrm{Nr} 63$ poz. 735.

Strużyński A. 2006. Skutki powodzi roztopowej w roku 2006 w uregulowanym odcinku delty śródlądowej rzeki Nidy. Infrastruktura i Ekologia Terenów Wiejskich, Komisja Technicznej Infrastruktury Wsi PAN Oddział Kraków, 4(1), 235-247.

Ustawa z dnia 20 lipca 2017 r. - Prawo wodne. Dz. U. 2017, poz. 1566.

Wolski K., Tyminski T., Dąbek. P.B. 2018. Assessment of the effect of vegetation on the transition of the flood wave using hydraulic 2D models. E3S Web of Conferences 44/00194, 1-8.

Wu W., He Zh. 2009. Effects of vegetation on flow conveyance and sediment transport capacity. International Journal of Sediment Research, 24(3), 247-259.

Prof. dr hab. inż. Bogusław Michalec

Department of Hydraulic Engineering and Geotechnics

University of Agriculture in Krakow

e-mail: rmmichbo@cyf-kr.edu.pl

ORCID: 0000-0002-0402-3416 